\title{
The Texas Republican Gerrymander of 2003: Was There an Effect on Congressional "Cheap Seats"?
}

\author{
Kenneth A. Wink
}

I examine the 2002, 2004, and 2006 Texas congressional elections to determine whether Republican redistricting in 2003 affected partisan turnout bias in subsequent elections. I use election results published in relevant issues of the Almanac of American Politics and from the website of the Texas Secretary of State's Office and apply James E. Campbell's (1996) calculation of partisan turnout bias. I find the Republican gerrymander did not reduce the Democratic advantage in turnout bias, suggesting that Republicans were somewhat restricted from affecting turnout bias by legal requirements to draw majority-minority districts and - more importantly-they probably had as their first priority the gaining of a favorable allocation or distributional bias rather than a favorable turnout bias in translating votes into seats.

In a recent study of the second U.S. House redistricting in Texas in the first decade of the new millennium, McKee et al. (2006) found that all five plans proposed by the Texas state legislature-including the plan eventually passed-were biased toward the Republicans. The pro-Republican bias of the redistricting plans came as no surprise, given the fact that Republicans had expressed dismay at the outcome of the 2002 House elections, in which Republican candidates received a majority of the statewide congressional vote but won only 15 of the 32 House seats. Republicans were further spurred to action by the perception that Texas Democrats had succeeded in avoiding the fates of their brethren in Alabama, Georgia, and North Carolina in the 1992 election and the mid-term election in 1994. Whereas Democrats in the southeast lost many U.S. House seats due to the creation of majorityminority districts in their states, Texas Democrats had cleverly drawn districts with bare majorities of Latinos and/or African-Americans and had combined urban and rural pro-Democratic constituencies to maintain their congressional majority (Hill 1995; Lublin 1997; Petrocik and Despasato 1998). When, after the smoke cleared from the 2002 state elections the Republicans had control of both houses of the legislature and the governorship in Texas for the first time since Reconstruction, GOP lawmakers found a legal loophole in the fact that the first redistricting plan was passed by

The data used in this analysis have been collected by the author and will be gladly shared with any interested readers.

KENNETH A. WINK is an associate professor of public administration and chair of the Department of Social Sciences at the University of Texas at Tyler.

The American Review of Politics, Vol. 30, Spring, 2009: 17-33

(C)2009 The American Review of Politics 
federal judges and never passed by the legislature. They seized their opportunity and pushed through a decidedly pro-Republican plan.

Using the methodology associated with Gelman and King's (1994) JudgeIt software program, McKee et al. (2006) identified levels of bias for the various Republican proposals and noted that Plan 1374C, the adopted plan, seemed likely to produce the highest level of pro-GOP bias in the short-term, when incumbency was taken into account. In the 2004 election, Republicans picked up a net gain of 6 seats, making the total Texas congressional delegation consist of 21 Republicans and 11 Democrats. ${ }^{1}$ The magnitude of the Republican swing in 2004 seems to confirm the existence of a pro-Republican "allocation" bias - the type of bias found by McKee et al.in the translation of seats to votes. But the size of the Republican tsunami in 2004 also begs another question: Did the Republican gerrymander succeed in making Democratic seats more costly to win or Republican seats less costly to win? In the words of James Campbell (1996), what happened to the Democratic "cheap seats" in the 2004 Texas House races? This article is an attempt to answer the question of how cheap seats were affected by the redistricting and what effect the change in cheap seats had on the final partisan makeup of the Texas congressional delegation, a question that looms large for other states in the southwestern U.S. (and, increasingly, nationwide) as the growth in the Latino population poses challenges to the achieving of fair representation for all ethnic groups.

\section{The Republican Gerrymander of 2003}

What did the Republicans do to alter the balance of power so greatly in the Texas congressional delegation? The Republicans targeted several Democrats for defeat and acted also to shore up the district of the lone Hispanic Republican Representative, Henry Bonilla. Max Sandlin (District 1) and Jim Turner (District 2) in East Texas, Nick Lampson (District 9) in Southeast Texas, Chet Edwards (District 11) in Central Texas, Charles Stenholm (District 17) in West Texas, and Martin Frost (District 24) in the Dallas-Fort Worth metroplex were the Democrats targeted for defeat. Before describing the Republican strategy in detail, it should be noted that Republicans had benefited even before the 2003 redistricting when Texas received two additional seats after the decennial census. Those two seats were created in high growth suburban areas and both were won by Republicans in 2002: the 31 st district stretched from suburban Houston to north of Austin and the 32nd was created in affluent, mostly Anglo areas of Dallas.

In East Texas, Districts 1 and 2, made up disproportionately of conservative Democrats living in rural counties, were sliced down and joined with a number of other districts having more concentrated areas of population. Max 
Sandlin was defeated by Republican Louie Gohmert in the newly drawn Tyler-based District 1. Jim Turner, the incumbent from District 2, decided to retire after his district was carved into Districts 1,2 , and 8 , all of which were won by Republicans.

In the Houston area, Districts 7, 8, 9, 14, and 25 were dramatically gerrymandered. District 7, already a safe Republican district, was drawn with a more heavily Anglo population than before, thus leaving surrounding districts more heavily populated with minority voters. District 9, Democratic incumbent Lampson's district, had consisted of the Galveston Bay area east and southeast of Houston (Galveston and Jefferson counties) and a small part of Houston proper. Heavily Anglo portions of Lampson's district were moved to the 2nd and 14th districts; indeed, Lampson ran for reelection in the 2nd district and was defeated by Republican Ted Poe and the 14th district became an even safer seat for Republican incumbent Ron Paul. Poe's effort was helped by the fact that the 8th District occupied by Republican incumbent Kevin Brady shed its north Harris county white suburban areas to Poe's district, pushing the safe Republican 8th further north and east to incorporate more rural (but still conservative) areas. Democratic incumbent Chris Bell had occupied a comfortable south Houston district (the 25th) made up of an eclectic mix of working-class Anglo, Hispanic, and black voters. After the GOP gerrymander, most of the African-American neighborhoods in the old 25th wound up in the newly drawn 9th district and Bell (an Anglo) was defeated by Al Green (an African-American) in the Democratic primary in 2004. Many of Bell's former Anglo and Hispanic constituents, meanwhile, found themselves in a district already safe for Democratic incumbent Gene Green (the 29th). When the cutting was done in the larger Houston area, the partisan tally went from five Democrats and four Republicans to three Democrats and six Republicans.

In central Texas, Chet Edwards' District 11, consisting of population based largely in Bell and McLennan counties, was literally split in two. Edwards ran for reelection in 2004 in the northern half of the old district, the newly drawn 17th, with his base in Waco (McLennan County). Despite having fewer African-Americans in District 17, Edwards eked out a 51 percent to 47 percent victory over Republican Arlene Wohlgemuth in the 2004 election, thus becoming the lone targeted Democrat to survive the Republican gerrymander.

Charlie Stenholm also experienced a division of his district into multiple new districts. The old 17 th had included population centers immediately west and northwest of Fort Worth, extending westward to include the cities of Abilene and San Angelo. After the 2003 redistricting, the only thing left was Abilene; the bulk of the population of the new district (the 19th) extended northwest to Lubbock and continued on to the New Mexico border. 
The problem for Stenholm is that Lubbock was the home base of Randy Neugebauer, a Republican first elected to the House in a special election in 2003. The result was that Stenholm, who had served in Congress since 1978, was crushed by Neugebauer 58 percent to 40 percent in the 2004 election; meanwhile, Republicans continued to control the three other districts into which parts of Stenholm's old district were merged.

Similar to Stenholm, Martin Frost found his district located in the midcities area between Dallas and Fort Worth perfectly situated to be carved into four different districts. It was, and Frost found himself living in the Dallas stronghold of Republican incumbent Pete Sessions' 32nd district. Although this move by the GOP was a bit risky in that significant Hispanic populations were merged into Sessions' once safe district, the result was another win for the GOP, with Sessions beating Frost 54 percent to 44 percent.

At the same time as the Democrats were targeted for defeat, Republican Henry Bonilla's district was made safer by the redistricting. His old district, the 23rd, had included suburbs of San Antonio but it also stretched westward nearly to El Paso, including the bulk of southwest Texas. The new 23rd brought in heavily Anglo Kendall and Kerr counties from the German Hill country and lopped off heavily Hispanic and Democratic leaning Laredo in the south. The result was that Bonilla defeated his Democratic opponent by 40 percent of the vote, a vast improvement over his 5 percent victory in 2002. However, a Democratic Party federal court challenge to the redistricting plan succeeded in having Bonilla's district redrawn again to resemble the old 23rd since Hispanic voting-age population (VAP) was reduced from approximately 63 percent of the total VAP to just under 50 percent. In the ensuing special election resulting from the federal court's decision, Bonilla lost 54 percent to 46 percent to former Democratic member of Congress Ciro Rodriguez. Special elections in Districts 15, 21, 22, 25, and 28 as a result of the litigation failed to change the balance of power since these districts were only changed slightly, although Democrat Nick Lampson won the contest in District 22 after Republican incumbent Tom DeLay resigned his seat after his much-publicized legal problems (Barone and Cohen 2003, 2005; Texas Legislative Council 2003a, 2003b).

In summary, the Republicans won a net gain of five seats by exercising different strategies in different parts of the state. In the Houston area, the packing of African-Americans and Hispanics into more homogeneous districts worked to the advantage of the GOP. In central Texas, slicing the African-American population was attempted but without much success. In East and West Texas, there was less a case of pairing Democratic incumbents as redrawing the districts of Democratic incumbents to include much of the population base of the districts of Republican incumbents. In Dallas, slicing minorities and the pairing of a Republican and Democratic incum- 
bent did the trick. In actuality, however, since changes in one or two districts affected a number of contiguous districts, one almost has to look at a state map to appreciate fully what the Republicans accomplished. Essentially, the Republicans used urban population centers spreading into rural areas to shift district lines with nearly surgical precision to advantage Republican incumbents and challengers and to weaken Democratic incumbents.

\section{The Nature of Partisan Bias}

Did the Republican redistricting have an impact on partisan bias, after all? That depends on the sort of partisan bias being measured. Partisan bias is generally understood to consist of inequity or asymmetry in the translation of partisan votes into party seats in the legislature. In legislative elections having single-member districts with plurality winner rules, the fact that the winning party typically wins a higher percentage of seats than popular votes is not sufficient to prove the existence of partisan bias. An electoral system is deemed biased when one party wins a higher or lower percentage of seats than would the other party, at some given percentage of the popular vote. Grofman et al. (1997) asserted that partisan bias can emerge under three conditions: (1) When the distribution of partisan voters differs by geographical area in such a way that one party wins an inflated seat share [distributional bias]; (2) When seats are allocated based on differences in population across constituencies [malapportionment bias]; (3) When one party's supporters turn out to vote at higher rates than their partisan opponents [turnout bias].

Most studies of partisan bias have used the JudgeIt methodology or King and Browning's (1987) logit model approach, which involves regressing a party's seat percentages on its vote percentages and identifying bias by the coefficient associated with the constant. In fact, there is a voluminous literature that spans many types of American elections in which researchers have followed one or the other of these approaches: Congressional elections (Brunell 1999; Gelman and King 1994b); U.S. state legislative elections (Browning and King 1987; Campagna 1991; Gelman and King 1994a; Gryski et al. 1990; Niemi and Jackman 1991); the electoral college (Garand and Parent 1991); and presidential primaries and caucuses (Ansolabahere and King 1990; Geer 1986) have all been analyzed. However, the direction and magnitude of bias in these studies has focused only on distributional (sometimes known as 'allocation') bias. Malapportionment bias is relevant in contexts such as the electoral college, since electoral votes are not allocated in direct proportion to population, but malapportionment bias in legislatures has been severely restricted by the 'one man, one vote' rulings of the U.S. Supreme Court. But turnout bias - that bias that may favor one 
party or the other due to systematic differences in voter turnout between the faithful from the respective parties - has not been greatly scrutinized.

James Campbell (1996) has been a leading proponent for the study of turnout bias. His study of U.S. House elections from 1952 to 1992 led him to conclude that the Democratic Party disproportionately won low turnout districts that Campbell identified as the 'cheap seats,' a finding confirmed by Wink and Weber (2005) in their study of U.S. state lower houses. Rather than focusing on partisan seat and vote percentages, Campbell analyzed actual votes and seats and found that Democratic congressional candidates frequently and systematically won their seats with fewer votes than their Republican counterparts. For Campbell, the fact the Democratic Party had fewer unwasted votes - those votes that went to winning candidates - than did the Republicans, was the key to understanding turnout bias.

Rather than using a historical approach to produce seats-votes curves over an extended time period (King and Browning 1987; Niemi and Jackman 1991; Rae 1967; Tufte 1973), the Campbell method can be used to examine partisan bias in individual election years. This advantage allows the immediate effects of redistricting on partisan bias to be examined, as well as the fairness of election results for each election year. The researcher simply uses election results district-by-district, in a given state in an election year. There is no need to determine the extent to which old district lines are different from new district lines; one simply notes the numerical results of each race at the conclusion of the election. To identify which party wins the 'cheap seats,' the researcher compares the average winning candidate votes for one of the two major parties in an election year, and calculates the total seats in the legislature that party would have won if they had won seats at the same vote totals as had all winners in that year. Then the percentage of seats the party would have won if they had won seats at the same vote totals for all winners is subtracted from the percentage of seats actually won by that party. This final figure is then subtracted from .50 to produce the "cheap seats" measure of partisan turnout bias. For this study, I calculate bias figures by analyzing the district results in 2002, 2004, and 2006, thus producing three measures of Democratic turnout bias, one for each year. It is therefore possible to study the Republican gerrymander of the Texas House to determine if partisan turnout bias was altered as Republicans benefited from a pro-GOP allocation bias by comparing the partisan direction and level of turnout bias in 2002 with the partisan direction and level of turnout bias in 2004 and 2006.

\section{Data and Methods}

In their study using JudgeIt, McKee et al. regressed the 2002 Democratic share of the two-party congressional vote on a number of explanatory 
variables (measured at the district level) and produced parameter estimates that were applied to the districts that would have been created by the five proposed plans. In essence, their effort was a simulation that attempted to forecast what would happen in the 2004 election. The present study, however, is a post-hoc analysis using 2002, 2004, and 2006 data which illustrates how partisan turnout bias was changed from pre-redistricting to postredistricting. Since the forecast of McKee et al. was highly accurate in predicting the partisan winners in each of the 32 House districts, one can be confident that their finding of a measurable Republican distributional or allocation bias did play out in the election of 2004. But how did the changing of the district lines in a pro-Republican manner affect turnout bias?

To answer this question, district-level election results from 2002, 2004, and 2006 were obtained from the Almanac of American Politics (Barone and Cohen, 2003; 2005; 2007) and from the website of the Office of the Secretary of State of Texas (http://elections.sos.state.tx.us) in cases in which uncontested election totals were not published in the former. Partisan bias measures were calculated for each election year in the manner prescribed by Campbell (1996). For example, in 2002 the mean vote of Texas Democratic winners was 79,821 . But all winning candidates earned a total of $3,040,616$ votes. Dividing the total number of votes cast for winning candidates by two, it can be determined that each major party in an unbiased system should have expended a total of 1,520,308 votes. Dividing this measure of "unwasted" votes in an unbiased system by the average number of votes for Democratic winners produces 19.05. Dividing 19.05 by the number of seats won by major party candidates (32) produces 0.595 , which represents the percentage of seats that would have been won by the Democrats if they had won 50 percent of the votes won by all winners. The final figure, referred to as partisan turnout bias, is calculated by subtracting 0.50 from 0.595 . Thus, in 2002, the Democrats benefited from a turnout bias of 9.5 percent. The question is did Republicans succeed in decreasing this turnout bias in favor of the Democrats by manipulating the district lines before the 2004 election?

\section{Were Democratic "Cheap Seats" Replaced by "Box Seats" in 2004?}

Before directly answering this question, it may help to step back and view the big picture. Table 1 provides descriptive statistics for the most important variable in the study, the votes earned by winners from the respective parties. Table 1 illustrates that in all three years in the study, it took a Republican candidate, on average, more votes to win a seat than it did for the typical Democratic candidate. In 2002, Republican winners expended over 32,000 more votes (a ratio of 1.41 to 1.0 ) than did Democratic winners, while in 2004 the gap between Republican winners and Democratic winners 

Table 1. Mean Votes of Winning Candidates, by Party,
U.S. House Races in Texas, 2002-2006

\begin{tabular}{lcccccc}
\hline & \multicolumn{2}{c}{2002} & \multicolumn{2}{c}{2004} & \multicolumn{2}{c}{2006} \\
Party & Dem. & Repub. & Dem. & Repub. & Dem. & Repub. \\
\hline Mean & 79,821 & 112,245 & 112,947 & 166,702 & 65,343 & 96,772 \\
Std. Dev. & 14,953 & 21,230 & 18,047 & 21,726 & 21,119 & 11,038 \\
N & 17 & 15 & 11 & 21 & 13 & 19 \\
\hline
\end{tabular}

grew to almost 54,000 votes (with a slightly larger ratio of 1.48 to 1.0 ). In 2006 , the difference was 31,429 votes on average, a figure closer to the 2002 measure but a ratio (1.48 to 1.0 ) that still seemingly advantaged the Democratic candidates. Of course, both party winners spent more votes to win in the presidential election year of 2004, but winning Republican vote expenditures increased 48.5 percent from 2002 to 2004, while Democratic winners' vote expenditures increased only by 41.5 percent. Then in 2006 both parties spent fewer votes in winning causes because of lower voter turnout in 2006. But the ratios presented above are instructive. According to the figures in Table 1, therefore, one can expect to find a Democratic turnout bias in 2002, 2004, and 2006, and the size of that pro-Democratic Party bias in 2004 and 2006 should be larger than the pre-redistricting turnout bias. In fact, even when one observes districts in which Republican vote expenditures were relatively low, those figures are still high relative to the comparable numbers for the Democrats. For example, one standard deviation below the mean, one finds Republican vote expenditures of 91,015 in 2002, 144,976 in 2004, and 85,734 in 2006, all of which exceed the Democratic winners' mean votes in the respective years.

In order to provide a measure of Campbell's partisan turnout bias in 2004 and 2006, one need only replicate the calculations described earlier using election data from those years. One other factor, however, should be accounted for as well. If there are a large number of uncontested or relatively uncompetitive races, or if there are a small number of such races that disproportionately affect one party, then the lack of competitiveness could have a profound impact on measures of party turnout bias. A perusal of the election results appears to support the proposition that uncontested or uncompetitive races should not have a large effect on the bias measures in 2002 or 2004. In 2002, there were 18 races in which the losing major party candidate received at least 25 percent of the two-party vote. In the fourteen uncompetitive races, each major party won seven contests, a fact that suggests bias measures will accurately reflect the aggregate differences in party 
vote spending for winning candidates. Similarly, in 2004 there were only eight uncompetitive races, with the Democrats winning three and the Republicans winning five. In 2006, there were nine uncompetitive elections; but in this year, the Democrats won seven of the nine less contested seats. For the sake of ensuring the robustness of the results despite this anomaly in 2006, the partisan bias is calculated with all races included and then with uncompetitive races excluded for the three election years. Following Gelman and King (1994) and McKee et al. (2006), who impute uncontested seats as earning 75 percent to 25 percent splits in their use of vote percentages with JudgeIt, we exclude seats in which the winning party earns greater than 75 percent of the two-party vote in our analysis of only contested elections. The results are reported in Table 2.

As illustrated in Table 2, pro-Democratic turnout biases are present in all years, whether or not uncompetitive races are excluded from the analysis. With all seats included, the bias grew from 9.5 percent in favor of the Democrats to 15.6 percent in favor of the Democrats, and then declined slightly in 2006 to a Democratic turnout bias of 14.3 percent. When only competitive seats are included in the analysis, the pro-Democratic bias rose from 7.7 percent to 15.7 percent, and again declined slightly to 13.1 percent in 2006. In both cases - with and without uncompetitive seats - the Republicans failed to decrease the pro-Democratic bias in either post-redistricting election. One can also express confidence in the results reported in Table 2 since in the respective years the measures of bias calculated with and without uncompetitive seats are nearly identical.

Finally, in Table 2, following Campbell (1996), I calculate the level of Democratic Party "seat inflation" due to turnout bias by multiplying the Democratic bias percentage by the number of seats contested. The seat inflation measure reflects the number of seats that supposedly were won by the

\section{Table 2. Partisan Turnout Bias for the Democratic Party, by All Districts and Competitive Districts, Texas U.S. House Races, 2002-2006}

\begin{tabular}{|c|c|c|c|c|c|c|}
\hline & \multicolumn{6}{|c|}{ Pro-Democratic Party Turnout Bias } \\
\hline & \multicolumn{2}{|c|}{2002} & \multicolumn{2}{|c|}{2004} & \multicolumn{2}{|c|}{2006} \\
\hline & $\begin{array}{c}\text { All } \\
+9.5 \%\end{array}$ & $\begin{array}{c}\text { Competitive } \\
+7.7 \%\end{array}$ & $\begin{array}{c}\text { All } \\
+15.6 \%\end{array}$ & $\begin{array}{c}\text { Competitive } \\
+15.7 \%\end{array}$ & $\begin{array}{c}\text { All } \\
+14.3 \%\end{array}$ & $\begin{array}{c}\text { Competitive } \\
0+13.1 \%\end{array}$ \\
\hline $\mathrm{N}=$ & 32 & 18 & 32 & 24 & 32 & 23 \\
\hline $\begin{array}{l}\text { Seat Inflation }= \\
\text { (bias * no. of seats) }\end{array}$ & 3.0 & 1.4 & 5.0 & 3.8 & 4.6 & 3.0 \\
\hline
\end{tabular}


Democrats, above what would have been won by them in an election system lacking turnout bias. Results are reported for all races and for only competitive races, in both election years. The Democratic seat inflation margin ranged from 1.4 seats (only competitive races) to 3.0 seats (all races) in 2002 , from 3.8 seats in competitive races to 5.0 seats in the contests for all the seats in 2004, and from 3.0 seats (only competitive races) to 4.6 seats (all races) in 2006. Interestingly, although Republican candidates picked up a net gain of 6 seats in 2004, increasing their total of 15 seats to 21, the analysis suggests that Democrats still won three or four seats more than they should have won in 2004 due to the cheap seats phenomenon. Then, the courtmandated redistricting after the 2004 elections reduced the Democratic seat inflation by approximately one seat in the 2006 election. Of course, there is a practical limit to the number of seats Republicans "should" have won under the current arrangement since there are 11 majority-minority districts (of 32 total districts) in the state, which exacerbates the tendency of Democrats to win in very low turnout districts (Texas Legislative Council 2003b). But the findings do beg the question of whether the drawing of these majorityminority districts produces a "fair" system in the sense that Democrats can win several seats with little effort and exhaustion of resources.

One objection to the findings in Tables 1 and 2 might be that the 2004 findings are an artifact of the presidential election of 2004. If voters knew George W. Bush would win the state of Texas easily, so the logic goes, Democrats might not turn out to vote. Then, in heavily Democratic districts, Democratic incumbents might win with fewer votes than normal and "artificially" inflate the Democratic turnout advantage. Texas voters do not express a party affiliation when they register to vote, so it is not possible to gauge the level of party turnout differences based on registration and voting data. However, one can examine the top of the respective tickets to infer whether one year was a stronger year for one party than the other and that turnout differences might result from those party trends. Upon examination, turnout in general was of course much higher in Texas in 2004 than in either 2002 or 2006. Turnout as a percentage of voting-age population was 46.1 percent in 2004 and only 29.4 percent and 26.4 percent in 2002 and 2006, respectively. But there is little evidence of a partisan differential to this increased turnout in 2004. Looking at the "top of the tickets," George W. Bush won an impressive 61.5 percent of the two-party vote in Texas in the 2004 presidential election. But, in 2002, Republican Rick Perry won an almost equally impressive 59.1 percent of the two-party vote in the gubernatorial race that year, and in 2006 Republican U.S. Senator Kay Bailey Hutchison won 63.1 percent of the two-party vote in her reelection bid. Therefore, it seems unlikely that the increased Democratic turnout bias in 2004 could have been greatly influenced by the fact that 2004 was a presidential election 
year with a popular native son running for the presidency atop the Republican ticket.

\section{Is the Republican Gerrymander of 2003 a Myth?}

How can it be that a redistricting plan that other scholars, pundits, and the media portrayed as a Republican gerrymander-and a plan that objectively increased the number of Republican seats in dramatic fashion-fails to cause Democrats to spend more votes to win their seats? Are McKee et al. (2006) simply wrong in their assessment that the congressional redistricting undertaken in Texas in 2003 was biased toward the Republicans? How can one account for this apparent anomaly?

The difference in findings can be attributed to the fact that there were different kinds of bias operating simultaneously in these elections. McKee et al. (2005) operationalize and measure distributional or allocation bias in their study. The fact is that the new district lines drawn for the 2004 election (which largely existed unchanged in 2006) were created primarily to insure that Republican vote percentages would exceed Democratic vote percentages in the majority of districts. In other words, the number of unwasted votes cast by Republicans was less relevant to GOP strategists than the number of votes wasted by the Democrats in losing causes. In fact, according to Campbell (1996), measures of distributional bias like those analyzed by McKee et al. (2006) are based on party differentials in wasted votes: "We should expect that the party winning the larger share of the popular vote would waste a small portion of that vote in losing causes $(1996,234)$." If the Republican redistricting effort in 2003 was a successful gerrymander that failed to produce more expensive victories for Democratic candidates, then it must be the case that the new district lines caused the Democratic votes that were cast in 2004 and 2006 to be spent on more losing causes relative to the Democratic votes that were cast in 2002.

Table 3 confirms that Democrats cast a much larger number of votes for losing candidates in 2004 and 2006 than in 2002. Conversely, Republicans actually cast fewer wasted votes in 2004 and 2006 than in 2002, even though 2004 was a presidential election year in which many more total votes were cast! Whereas the number of Democratic wasted votes nearly tripled from 2002 to 2004 and remained higher in 2006 than in 2002, the number of Republican votes cast in losing efforts actually declined by 19 percent from 2002 to 2004 and dropped again in 2006. As Table 3 indicates, 46.5 percent of the votes cast for losing candidates in 2002 were Democratic votes; in 2004 and 2006, Democrats cast over 74 percent and over 75 percent, respectively, of the total votes spent in losing causes. On average, across the 32 districts, Democrats cast - on average - almost twice as many votes as 
Table 3. Votes Cast for Losing Candidates, by Party, U.S. House Races in Texas, 2002-2006

\begin{tabular}{|c|c|c|c|c|c|c|}
\hline \multirow[b]{2}{*}{ Party } & \multicolumn{2}{|c|}{2002} & \multicolumn{2}{|c|}{2004} & \multicolumn{2}{|c|}{2006} \\
\hline & Dem. & Repub. & Dem. & Repub. & Dem. & Repub. \\
\hline $\begin{array}{l}\text { Total Votes } \\
\text { Cast for Losing } \\
\text { Candidates }\end{array}$ & 528,222 & 607,053 & $1,471,551$ & 511,791 & 965,325 & 317,206 \\
\hline $\begin{array}{l}\text { Percentage of Major } \\
\text { Party Votes Cast for } \\
\text { Losing Candidates }\end{array}$ & .465 & .535 & .742 & .258 & .753 & .247 \\
\hline $\begin{array}{l}\text { Mean Party Votes } \\
\text { Cast for Losing } \\
\text { Candidates }\end{array}$ & 35,215 & 35,709 & 70,074 & 46,526 & 50,807 & 24,400 \\
\hline Seats Won & 17 & 15 & 11 & 21 & 13 & 19 \\
\hline $\begin{array}{l}\text { Percentage of } \\
\text { Seats Won }\end{array}$ & .531 & .469 & .344 & .656 & .406 & .594 \\
\hline
\end{tabular}

Republicans for losing candidates in 2004 and over twice as many in 2006. The Republicans were extremely efficient in producing distributional or allocation bias toward the GOP across the 32 districts, a fact that more than made up for the lack of additional costs borne by Democratic winners.

Two more points should be made about turnout bias. First, there are limits on what state legislatures can do. All states are required to use census data - rather than voter turnout or voter registration figures - as the basis for drawing congressional district lines. Furthermore, the Voting Rights Act of 1965 required preclearance by the U.S. Department of Justice of the congressional redistricting plans in the Deep South. As the number of states under preclearance was later expanded and as Congress extended protected status to language minorities in 1975, more state legislatures-including the one in Texas, of course-were required to create the maximum number of African-American and Latino majority districts as possible (Lublin 2004, 99-101). Thus, the Texas GOP did not have a free hand to minimize their turnout bias disadvantage. ${ }^{2}$

Second, there is the question of whether turnout bias is - or should be-a major concern for the party in control of the redistricting process. While distributional or allocation bias should result in a change in seats in favor of the party experiencing the favorable bias, what is the evidence regarding the relationship between seats won and turnout bias? As noted earlier, Democratic turnout bias actually increased in Texas U.S. House 
races after 2003, despite the fact that Democrats actually lost seats in the two races after 2002. Perhaps surprisingly, the bivariate correlations between Democratic bias and Democratic seats won in the elections from 2002 to 2006 are $-.992(\mathrm{p}=.083)$ when all races are included and $-.844(\mathrm{p}=.361)$ when uncompetitive races are included. Obviously, with only three years of cases, we do not find the levels of statistical significance we would wish to see, but the strong, negative correlations between turnout bias and seats won by the party experiencing the favorable bias are suggestive.

To test further the possibility that turnout bias and success in winning seats might be negatively correlated, I borrowed from the extensive array of data presented by Campbell in the appendices of his study (1996, Table B.1 and Table B.4, pp. 235, 239). Campbell presents the Democratic seats percentages won and the unwasted votes measure of Democratic turnout bias for contested races in each election for the U.S. House from 1954-1992. I found the bivariate correlation of those two variables to be $-.656(\mathrm{p}=.002)$. The findings from the test using the Campbell data indicate strongly that the higher the pro-Democratic levels of turnout bias, the lower the percentage of seats won by the Democrats!

\section{Conclusion}

What are we to conclude from this analysis? First, it is possible to measure partisan turnout bias and apply it to a particular election or set of elections. While partisan turnout bias has been applied to U.S. House races and state lower-house races to describe the relationship between partisan votes and partisan seat allocation over lengthy periods of time, in this paper, I have used the cheap seats measure in a unique way, to analyze a specific attempt by the dominant party in a state to redraw congressional district lines to the advantage of that party's congressional candidates. Although this exercise is a straightforward effort to measure the success of a particular redistricting, it also has implications for the larger issue of fair representation, both in terms of translating partisan votes into partisan seats and in terms of achieving fair representation for large ethnic and racial groups in the increasingly diversely populated United States.

Second, partisan turnout bias might not work in quite the manner Campbell and other scholars have imagined. Since cheap seats are legislative seats won rather inexpensively with low voter turnout, one might expect that the majority party could redraw district lines in such a way as to make winning efforts more costly for the minority party in the state. In the present study, I found the Republicans did not succeed in making Democratic victories more costly by requiring more votes to win those seats. Instead, I found the Republicans' new districts caused Democrats to "waste" many more 
votes in losing efforts. Rather than forcing Democrats to turn out to vote at higher rates in order to win more seats, the Republicans simply ensured GOP candidates would likely win a majority of newly redrawn districts, assuming normal voter turnout for each party. Thus, Democratic votes that in the past would have been spent in winning efforts were cast for losing candidates in 2004 and 2006. In fact, the number of votes cast for losing Democratic candidates tripled from 2002 to 2004, despite the fact that Republican votes for losers actually fell in 2004.

Third, despite the findings that suggest that partisan turnout bias does not work in an intuitive manner, findings presented here do not support the proposition that the cheap seats phenomenon is mythical or unimportant. As Grofman et al. (1997) have noted both turnout bias and distributional bias are legitimate concepts in attempting to determine the fairness of plans that turn partisan votes into seat allocations. Indeed, since Democratic winners still paid a smaller cost for their elections victories than did Republican winners in 2004, I noted that Democrats probably won more seats than they would have if their winning seats had been more costly, everything else being equal. But in 2004, everything else was not equal. Distributional or allocation bias was so powerful in support of the GOP that there was a sixseat swing in the total partisan division of seats from 2002 to 2004. This was certainly the primary intention of the Republican state legislators all along.

Scholars may, therefore, wish to examine particular elections to determine, in fact, if there may be an inverse relationship between distributional bias and turnout bias in cases of very effective redistricting efforts. In other words, while turnout bias may have negative connotations for the party that controls redistricting and is on the losing end of turnout bias, it may be that clever gerrymandering to enhance distributional bias can win seats for the dominant party because packing schemes increase turnout bias toward the party that lost seats. Thus, while it may be true that there will always be some Democratic turnout bias because Democratic voters turn out at lower rates than Republican voters, scholars in the future might wish to examine the relationships between distributional bias, turnout bias, and seats won in elections to determine if the results suggested in the present study can generally be observed in other contexts.

In some respects, turnout bias may be even more relevant to the discussion of fair elections today than in the years Campbell studied. For example, Texas Republicans may have been able to use the Voting Rights Act to create a distributional bias, if not a turnout bias, in their favor, in the 2003 redistricting. In almost all districts in which there are Hispanic Democratic members of Congress in Texas, the Hispanic population exceeds twothirds of the population, partly due to the prevalence of large Hispanic populations in border counties but perhaps in some cases because of "pack- 
ing" (see Lublin 2004). Furthermore, the state legislature cannot resort to "cracking" minority populations into small ineffectual percentages - a tool to preserve the power of white Democrats in the South for decades-because of the extension of the Voting Rights Act of 1965 to prohibit the practice (Black and Black 2002; Butler and Cain 1992; Canon 1999; Lublin 1997). Thus, the three districts in which there are African-American Democratic members of Congress in Texas are not likely to have their African-American populations diluted through clever redistricting strategies, although in all three of these districts there are substantial Hispanic populations (Barone and Cohen 2005; Texas Legislative Council 2006). Regardless of whether these seats are won in the future by African-Americans or Latinos, however, turnout is likely to be low, the winners are likely to be Democrats, and there will continue to be a Democratic Party turnout bias.

The implications of redistricting to provide ethnic and partisan representation will continue to be felt in Texas, California, Illinois, and New York, states with urban centers having diverse populations. Cheap seats are likely to be present for a long time due to legally mandated majority-minority districts and housing patterns that reflect distinct socioeconomic (and partisan) cleavages (Abramowitz et al. 2006). It will be interesting to see, therefore, if turnout bias remains largely academic, placed on the backburner as practitioners focus on enhancing a party's distributional bias, or if variation in turnout bias becomes a more central focus of legislative activity or legal challenge in the future. While the advantages and disadvantages of creating majority-minority districts has been debated and will continue to be debated (e.g., Cameron et al. 1996; Canon 1999; Lublin 1997; Petrocik and Desposato 1998; Thernstrom and Thernstrom 1997), partisan turnout bias may be a measurable variable that can be a part of the larger debate over fair legislative elections (e.g., Brunell 2006).

\section{NOTES}

${ }^{1}$ It should be noted that Ralph Hall, a Representative from East Texas, ran as a Democrat in 2002 and a Republican in 2004. Although one could argue that the actual seat swing due to redistricting produced only five new Republican seats since Hall was not defeated as a Democrat, Hall became a Republican convert when it became apparent the new redistricting would place him in a district with more suburban portions of the eastern Dallas region as compared to his more rural East Texas district of 2002. The fact that the new redistricting plan had just been upheld by the federal courts almost certainly led to Hall's decision to change party affiliation.

${ }^{2}$ As an example, a federal appellate court threw out the 2004 district of Henry Bonilla, the only Hispanic Republican in the Texas congressional delegation, in League of United Latin American Citizens (LULAC) v. Perry (2006). The Republicans had protected Bonilla from dwindling victory margins by adding Anglos from counties northwest 
of San Antonio to his district. But the formerly majority Hispanic voting-age population declined to less than $50 \%$ as a result of the GOP plan, and the redrawing of the district by the court led to Bonilla's defeat in a special election in 2006 (Office of the Texas Secretary of State, 2006).

\section{REFERENCES}

Abramowitz, Alan, Brad Alexander, and Matthew Gunning. 2006. Don't Blame Redistricting for Uncompetitive Elections. PS: Political Science and Politics 39:87-90.

Ansolabahere, Stephen, and Gary King. 1990. Measuring the Consequences of Delegation Selection Rules in Presidential Nominations. Journal of Politics 52:609-621.

Barone, Michael, with Richard E. Cohen. 2005. The Almanac of American Politics 2006. Washington, D.C.: National Journal Group.

Black, Earl, and Merle Black. 2002. The Rise of Southern Republicans. Cambridge, MA: Harvard University Press.

Browning, Robert X., and Gary King. 1987. Seats, Votes, and Gerrymandering. Law and Policy 9:305-322.

Brunell, Thomas. 1999. Partisan Bias in U.S. Congressional Elections, 1952-1996: Why the Senate is Usually More Republican than the House of Representatives. American Politics Quarterly 27:316-337.

Brunell, Thomas. 2006. Rethinking Redistricting: How Drawing Uncompetitive Districts Eliminates Gerrymanders, Enhances Representation, and Improves Attitudes toward Congress. PS: Political Science and Politics 39:77-85.

Butler, David, and Bruce Cain. 1992. Congressional Redistricting: Comparative and Theoretical Perspectives. New York: MacMillan.

Cameron, Charles, David Epstein, and Sharyn O'Halloran. 1996. Do Majority-Minority Districts Maximize Substantive Black Representation in Congress? American Political Science Review 90:794-812.

Campagna, Janet. 1991. Bias and Responsiveness in the Seat-Vote Relationship. Legislative Studies Quarterly 16:81-89.

Campbell, James E. 1996. Cheap Seats: The Democratic Party's Advantage in U.S. House Elections. Columbus: Ohio State University Press.

Canon, David T. 1999. Race, Redistricting, and Representation: The Unintended Consequences of Black Majority Districts. Chicago: University of Chicago Press.

Garand, James C., and T. Wayne Parent. 1991. Representation, Swing, and Bias in U.S. Presidential Elections: 1872-1988. American Journal of Political Science 35:10111031.

Geer, John G. 1986. Rules Governing Presidential Primaries. Journal of Politics 48:10061025 .

Gelman, Andrew, and Gary King. 1994a. Enhancing Democracy Through Legislative Redistricting. American Political Science Review 88:541-559.

Gelman, Andrew, and Gary King. 1994b. A Unified Method of Evaluating Electoral Systems and Redistricting Plans. American Journal of Political Science 38:514-554.

Grofman, Bernard, William Koetzle, and Thomas Brunell. 1997. An Integrated Perspective on the Three Potential Sources of Partisan Bias: Malapportionment, Turnout Differences, and the Geographic Distribution of Party Vote Shares. Electoral Studies 16:457-470. 
Gryski Gerard S., Bruce Reed, and Euel Elliott. 1990. The Votes-Seats Relationship in State Legislative Elections. American Politics Quarterly 18:141-157.

King, Gary, and Robert X. Browning. 1987. Democratic Representation and Partisan Bias in Congressional Elections. American Political Science Review 81:1251-1273.

Lublin, David. 1997. The Paradox of Representation: Racial Gerrymandering and Minority Interests in Congress. Princeton, NJ: Princeton University Press.

Lublin, David. 2004. The Republican South: Democratization and Partisan Change. Princeton, NJ: Princeton University Press.

McKee, Seth C., Jeremy M. Teigen, and Matieu Turgeon. 2006. The Partisan Impact of Congressional Redistricting: The Case of Texas, 2001-2003. Social Science Quarterly 86:308-317.

Niemi, Richard G., and Simon Jackman. 1991. Bias and Responsiveness in State Legislative Districting. Legislative Studies Quarterly 16:183-202.

Office of the Texas Secretary of State. 2006. Historical Election Results. http://elections.sos.state.tx.us.

Petrocik, John, and Scott Desposato. 1998. The Partisan Consequences of MajorityMinority Redistricting in the South, 1992 and 1994. Journal of Politics 60:613-633.

Rae, Douglas W. 1967. The Political Consequences of Election Laws. New Haven, CT: Yale University Press.

Texas Legislative Council. 2006. Texas Redistricting: Opinions, Orders, Maps. http://www.tlc.state.tx.us/redist/pdf/opinion080406.pdf. Accessed May 21, 2007.

Thernstrom, Stephan, and Abigail Thernstrom. 1997. America in Black and White: One Nation, Indivisible. New York: Touchstone.

Tufte, Edward R. 1973. The Relationship between Seats and Votes in Two-Party Systems. American Political Science Review 67:540-554.

Wink, Kenneth A., and Ronald E. Weber. 2005. Do Democrats and Republicans Pay the Same Price for Seats in U.S. State Lower House Elections? An Analysis of 'Cheap Seats' in Forty-four States. American Review of Politics 26:305-322. 